\title{
Effect of Substituting Soybean Meal with Moringa oleifera Meal on the Growth and Body Composition of Labeo rohita Fingerlings
}

\author{
Daniel Masood ${ }^{1}$, Noor Khan ${ }^{1 *}$, Khalid Javed Iqbal' ${ }^{2}$, Sadaf Dogar', Abdul Hanan', \\ Sadia Nazir', Sheeza Bano ${ }^{1}$, Azra Anwar ${ }^{2}$, Sameul A.M. Martin ${ }^{3}$ \\ and Chris J. Secombes ${ }^{3}$ \\ ${ }^{1}$ Department of Fisheries and Aquaculture, University of Veterinary and Animal \\ Sciences, Lahore \\ ${ }^{2}$ Department of Zoology, The Islamia University of Bahawalpur, Pakistan \\ ${ }^{3}$ School of Biological Sciences, University of Aberdeen, United Kingdom
}

\begin{abstract}
A B S T R A C T
The present study was conducted to examine the effect of replacing soybean meal in fish diets with the cheaper alternative plant protein moringa meal (Moringa oleifera) on growth and body composition of Labeo rohita fingerlings. L. rohita (average weight $190.25 \pm 00 \mathrm{~g}$ ) were stocked randomly in glass aquaria for a 90 day feeding trial. Fish were fed twice daily with four different iso-nitrogenous diets at a feeding level of $3 \%$ of total biomass. The diets contained $26 \%$ crude protein in which moringa meal substituted soybean meal at $0 \%$ (control), $10 \%, 20 \%$ and $30 \%$, with the groups fed these diets designated as $\mathrm{T}_{0}, \mathrm{~T}_{1}$, $\mathrm{T}_{2}$ and $\mathrm{T}_{3}$, respectively. The highest weight gain $(254.00 \pm 4.24 \mathrm{~g})$ was recorded in $\mathrm{T}_{3}$ and lowest in $\mathrm{T}_{0}$ $(80.97 \pm 17.80 \mathrm{~g})$. Significant differences $(\mathrm{P}<0.01)$ were observed in the feed conversion ratio $(\mathrm{FCR})$ between $\mathrm{T}_{3}(1.81 \pm 0.06)$ and $\mathrm{T}_{1}(2.70 \pm 0.13)$ and specific growth rate $(\mathrm{SGR})$ of $\mathrm{T}_{3}(0.42 \pm 00)$ and $\mathrm{T}_{1}$ $(0.25 \pm 0.01)$. These findings indicated that $M$. oleifera meal has good potential to substitute soybean meal as a relatively cheap and good quality plant protein source without any harmful effects on fish body composition.
\end{abstract}
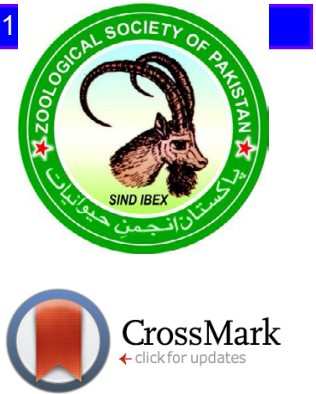

Article Information

Received 15 August 2019

Revised 12 September 2019

Accepted 25 September 2019

Available online 13 May 2020

Authors' Contribution

DM and NK planned the research.

KJI, NK, AA, SAMM and CJS wrote

the manuscript. SD, AH, SN and SB

performed lab work. NK and KJI

analysed the data statistically.

Key words

Labeo rohita, Growth parameters,

Body composition, Moringa oleifera,

Vital organs histology

\section{INTRODUCTION}

$\mathrm{F}$ ish is an excellent source of vitamins, essential minerals, high quality protein and unsaturated fatty acid (Petricorena, 2014). The demand for fish production via aquaculture is increasing to fulfill the protein requirement in human diets across the globe. The principal input in fish production is the feed, with high prices and limited supply of fish meal, major constraints in the aqua feed industry (Gabriel et al., 2007). Therefore, fish culturists are currently focusing on replacement of high cost animal ingredients with natural high quality plant proteins for fish feed formulation to reduce the cost (Hashem et al., 2017). Plant based protein source for fish feed, especially of soybean meal (SBM), have been extensively used in aquaculture production (Storebakken et al., 2000; Barros et $a l ., 2002)$. However, excess reliance on SBM may increase its price. Therefore, exploitation and consumption of other low-cost plant based protein sources for fish feed will help

\footnotetext{
* Corresponding author: nkhanuvas@gmail.com 0030-9923/2020/0005-1745 \$ 9.00/0

Copyright 2020 Zoological Society of Pakistan
}

reduce the feed cost and with the added benefit that there is evidence that diversifying the source of plant proteins may be beneficial to the fish (Hashem et al., 2017).

Plants contain many bioactive compounds that are bio-degradable, ecofriendly and easily available, and can have antioxidant, antiviral and antibacterial properties (Citarasu, 2010). When used in fish nutrition these compounds can activate immune responses, enhance the secretion of digestive enzymes and stimulate the feed intake (Citarasu, 2010). In the aqua feed industry, many plants and plant products are used as functional feeds for boosting immunity, preventing infections, promoting growth, reducing stress and stimulating appetite for producing healthy fishes (Shalaby, 2004).

Many plants have been investigated for their natural potential to replace fish meal in aqua feed preparation. Amongst these Moringa oleifera, belonging to the family Moringaceae, is a rapidly growing plant found in tropical and subtropical areas. The leaves of $M$. oleifera are a rich source of proteins, vitamins and minerals. Hence $M$. oleifera is commonly known around the globe as "The Miracle Tree" or "Ben oil tree" due to its high nutritional value and medicinal uses (Luqman et al., 2012). Indeed, it 
is used for the treatment of many human health conditions including malnutrition and cardiovascular disease, and possessed diuretic properties, is hepatoprotective, has antiulcer effects and lowers cholesterol levels (Luqman et al., 2012).

The $M$. oleifera leaves contain a high proportion of crude protein, varying from $25 \%$ to $32 \%$ (Makkar and Becker, 1996; Soliva et al., 2005). This protein is easily digestible due to the presence of a low content of acid detergent insoluble protein (1 to $2 \%$ ) and high content of pepsin soluble protein ( 82 to 91\%) (Makkar and Becker, 1996). The leaves of $M$. oleifera have been reported previously to be an excellent fish meal substitute in the diet of north African catfish Clarias gariepinus and roho labeo Labeo rohita fingerlings up to a $10 \%$ inclusion level (Ozovehe et al., 2013; Ezekiel et al., 2016; Arsalan et al., 2016; Mehdi et al., 2016). Furthermore, seed meal of M. oleifera has also been explored as a good alternative plant based protein feed in Nile tilapia (Oreochromis niloticus) fingerlings (Hashem et al., 2017). With this in mind the present study was designed to evaluate the potential of $M$. oleifera meal to replace soybean meal in diets for $L$. rohita and also to analyze its effects on growth, body composition, liver and gut health of $L$. rohita fingerlings.

\section{MATERIALS AND METHODS}

\section{Study site, experimental fish and procedure}

The experiment was conducted at Fish Seed Hatchery of the Department of Fisheries and Aquaculture, University of Veterinary and Animal Sciences (UVAS), Ravi Campus, Pattoki. The fish L. rohita (average weight 190.25 $\pm 00 \mathrm{~g}$ ) were collected from fish ponds at UVAS Ravi Campus Pattoki, Punjab, Pakistan and stocked randomly in 8 aquaria $(60.96 \times 55.88 \times 40.64 \mathrm{~cm})$ at $15 \mathrm{fish} /$ aquarium. Before stocking fish net body weight and length were measured and recorded. The feeding trial lasted for 90 days.

\section{Collection of Moringa oleifera and processing}

M. oleifera leaves were collected from Bahawalpur and washed with freshwater to remove all contaminants, properly drained and dried under shade for 1 week. Thereafter, dried leaves were crushed into a fine powder with an electric grinder and stored in opaque, air tight plastic zipper packets.

\section{Fish feed formulation}

Four types of experimental feeds containing 26\% crude protein were formulated (Table I), with differing inclusion levels of $M$. oleifera meal, with other nutrients from soybean meal, fish meal, rice polish, wheat bran, sunflower meal and nutrimix. The $M$. oleifera meal was incorporated into each diet to give levels of $0 \%$ (control), $10 \%, 20 \%$ and $30 \%$, with the fish fed these diets designated as $\mathrm{T}_{0}, \mathrm{~T}_{1}, \mathrm{~T}_{2}$ and $\mathrm{T}_{3}$, respectively. Experimental diets were analyzed using proximate analyses. All analyses followed the procedure described by AOAC (2006). Feed ingredients were mixed thoroughly and a sufficient amount of water was added for smooth pelleting. Pellets $(2 \mathrm{~mm})$ were then formed using a local pelleting machine and stored in the air tight packaging until use.

\section{Feeding protocol}

The $L$. rohita fingerlings were fed twice a day at 7:30 - 8:30 AM and 2:30 - 3:30 PM at a rate of 3\% of total body weight per day. Feed quantity was recalculated every fortnight.

\section{Determination of growth parameters of fish}

Growth parameters of fish, such as initial weight and length, were measured before stocking. At the end of trial other parameters such as final weight, feed conversion ratio (FCR), percentage weight gain, net gain in weight and specific growth rate (SGR) were also recorded.

\section{Physico-chemical parameters of water}

All physico-chemical parameters of aquarium water such as dissolved oxygen (DO), temperature, salinity, electrical conductivity, $\mathrm{pH}$ and total dissolved solids (TDS) were recorded on a daily basis using a dissolved oxygen meter and multi meter, except nitrates which were recorded on a fortnightly basis using HANNA Nitrate Test Kit HI3874.

\section{Statistical analysis}

The results of body composition, growth and physicochemical parameters were analyzed using one way analysis of variance (ANOVA) using statistical software SAS version 9.1 .

\section{RESULTS}

Statistically significant $(\mathrm{P} \leq 0.05)$ differences were recorded in growth parameters of all treatment groups (Table II). The maximum weight gain $(254.00 \pm 4.24 \mathrm{~g})$ was observed in $\mathrm{T}_{3}$ followed by $\mathrm{T}_{1}(127.50 \pm 9.19 \mathrm{~g}), \mathrm{T}_{2}$ $(198.50 \pm 20.50 \mathrm{~g})$ and control $\mathrm{T}_{0}(80.97 \pm 17.80 \mathrm{~g})$. Highest length increase $(85.10 \pm 0.98 \mathrm{~cm})$ was found in $\mathrm{T}_{2}$, followed by $\mathrm{T}_{0}(78.10 \pm 1.83 \mathrm{~cm}), \mathrm{T}_{1}(75.95 \pm 4.59 \mathrm{~cm})$, and $\mathrm{T}_{3}$ $(74.20 \pm 3.95 \mathrm{~cm})$. Significant differences $(\mathrm{P}<0.01)$ were observed in the feed conversion ratio (FCR) between $\mathrm{T}_{3}$ $(1.81 \pm 0.06)$ and $T_{1}(2.70 \pm 0.13)$ and specific growth rate (SGR \%) of $\mathrm{T}_{3}(0.42 \pm 00)$ and $\mathrm{T} 1(0.25 \pm 0.01)$. The lowest $(0.25 \pm 0.01)$ specific growth rate was recorded in fish fed 
Table I. Fish feed formulation replacing soybean with Moringa oleifera meal.

\begin{tabular}{|c|c|c|c|c|c|c|c|c|c|c|}
\hline \multirow[t]{2}{*}{ Ingredients } & \multicolumn{3}{|c|}{ Control } & \multicolumn{3}{|c|}{$10 \%$ Moringa meal } & \multicolumn{2}{|c|}{$20 \%$ Moringa meal } & \multicolumn{2}{|c|}{$30 \%$ Moringa meal } \\
\hline & $\begin{array}{l}\text { Crude protein } \\
\text { (CP) \% of } \\
\text { ingredients }\end{array}$ & $\begin{array}{l}\text { Inclu- } \\
\text { sion } \\
\text { level }\end{array}$ & $\begin{array}{l}\text { Contri- } \\
\text { bution of } \\
\text { CP \% }\end{array}$ & $\begin{array}{l}\text { Crude } \\
\text { protein }\end{array}$ & $\begin{array}{l}\text { Inclu- } \\
\text { sion } \\
\text { level }\end{array}$ & $\begin{array}{l}\text { Contri- } \\
\text { bution of } \\
\text { CP \% }\end{array}$ & $\begin{array}{l}\text { Inclusion } \\
\text { level }\end{array}$ & $\begin{array}{l}\text { Contribu- } \\
\text { tion of CP } \\
\%\end{array}$ & $\begin{array}{l}\text { Inclusion } \\
\text { level }\end{array}$ & $\begin{array}{l}\text { Contribu- } \\
\text { tion of CP } \\
\%\end{array}$ \\
\hline Fish meal & 52.72 & 4 & 2.1 & 52.72 & 7 & 3.7 & 8 & 4.2 & 11 & 5.8 \\
\hline Rice polish & 15.1 & 29.5 & 4.5 & 15.1 & 22 & 3.3 & 15 & 2.3 & 9 & 1.4 \\
\hline Wheat bran & 16.4 & 23 & 3.8 & 16.4 & 21 & 3.4 & 13 & 2.1 & 10 & 1.6 \\
\hline Sunflower meal & 30.23 & 4 & 1.2 & 30.23 & 5.5 & 1.6 & 19.5 & 5.9 & 25.5 & 7.7 \\
\hline Soybean meal & 43.09 & 35 & 15.1 & 43.09 & 30 & 13 & 20 & 8.6 & 10 & 4.3 \\
\hline Moringa meal & -- & -- & -- & 18 & 10 & 1.8 & 20 & 3.6 & 30 & 5.4 \\
\hline Vitamins & & 4 & 0 & & 4 & 0 & 4 & 0 & 4 & 0 \\
\hline Molasses & & 0.5 & 0 & & 0.5 & 0 & 0.5 & 0 & 0.5 & 0 \\
\hline Total & & 100 & 26.63 & & 100 & 26.8 & 100 & 26.7 & 100 & 26.2 \\
\hline
\end{tabular}

Table II. Effect of varying levels of Moringa oleifera meal in fish diets on the growth parameters of Labeo rohita.

\begin{tabular}{lllll}
\hline Parameters & Control & $\mathbf{T}_{1}$ & $\mathbf{T}_{2}$ & $\mathbf{T}_{3}$ \\
\hline Weight gain(g) & $80.97 \pm 17.80^{\mathrm{d}}$ & $127.50 \pm 9.19^{\mathrm{c}}$ & $198.50 \pm 20.50^{\mathrm{b}}$ & $254.00 \pm 4.24^{\mathrm{a}}$ \\
Increase in length(cm) & $78.10 \pm 1.83^{\mathrm{a}}$ & $75.95 \pm 4.59^{\mathrm{a}}$ & $85.10 \pm 0.98^{\mathrm{b}}$ & $74.20 \pm 3.95^{\mathrm{a}}$ \\
\% weight gain & $23.89 \pm 5.35^{\mathrm{d}}$ & $67.09 \pm 4.82^{\mathrm{c}}$ & $102.00 \pm 14.14^{\mathrm{b}}$ & $140.00 \pm 1.41^{\mathrm{a}}$ \\
FCR & $2.38 \pm 0.43^{\mathrm{a}}$ & $2.70 \pm 0.13^{\mathrm{a}}$ & $1.96 \pm 0.18^{\mathrm{b}}$ & $1.81 \pm 0.06^{\mathrm{b}}$ \\
SGR & $0.28 \pm 0.06^{\mathrm{d}}$ & $0.25 \pm 0.01^{\mathrm{c}}$ & $0.33 \pm 0.03^{\mathrm{b}}$ & $0.42 \pm 00^{\mathrm{a}}$ \\
\hline
\end{tabular}

$\mathrm{T}_{1}, 10 \%$ Moringa meal; $\mathrm{T}_{2}, 20 \%$ Moringa meal; $\mathrm{T}_{3,} 30 \%$ Moringa meal.

Table III. Proximate analysis of Labeo rohita fed on different Moringa oleifera meal diets.

\begin{tabular}{lllll}
\hline Parameters & Control & $\mathbf{T}_{1}$ & $\mathbf{T}_{2}$ & $\mathbf{T}_{\mathbf{3}}$ \\
\hline Crude protein \% & $59.41 \pm 0.79^{\mathrm{b}}$ & $61.82 \pm 0.10^{\mathrm{a}}$ & $60.26 \pm 0.28^{\mathrm{b}}$ & $62.45 \pm 0.15^{\mathrm{a}}$ \\
Crude fat\% & $5.70 \pm 0.05^{\mathrm{d}}$ & $6.53 \pm 0.04^{\mathrm{c}}$ & $8.67 \pm 0.03^{\mathrm{a}}$ & $7.43 \pm 0.04^{\mathrm{b}}$ \\
Ash\% & $6.80 \pm 0.08^{\mathrm{a}}$ & $4.60 \pm 0.28^{\mathrm{b}}$ & $4.73 \pm 0.12^{\mathrm{b}}$ & $4.66 \pm 0.16^{\mathrm{b}}$ \\
Moisture\% & $5.90 \pm 0.84^{\mathrm{a}}$ & $5.60 \pm 0.56^{\mathrm{a}}$ & $4.50 \pm 0.70^{\mathrm{a}}$ & $4.45 \pm 0.07^{\mathrm{a}}$ \\
Dry matter\% & $94.10 \pm 0.84^{\mathrm{ab}}$ & $93.40 \pm 0.56^{\mathrm{b}}$ & $95.50 \pm 0.70^{\mathrm{a}}$ & $95.45 \pm 0.07^{\mathrm{a}}$ \\
\hline
\end{tabular}

For abbreviations, see Table II.

Table IV. Physico-chemical analysis of aquarium water cultured Labeo rohita under various treatments.

\begin{tabular}{lllll}
\hline Parameters & Control & $\mathbf{T}_{1}$ & $\mathbf{T}_{\mathbf{2}}$ & $\mathbf{T}_{\mathbf{3}}$ \\
\hline Temperature $\left({ }^{\circ} \mathrm{C}\right)$ & $22.83 \pm 2.70^{\mathrm{a}}$ & $22.38 \pm 2.54^{\mathrm{a}}$ & $21.97 \pm 2.91^{\mathrm{a}}$ & $22.28 \pm 3.13^{\mathrm{a}}$ \\
DO $(\mathrm{mg} / \mathrm{L})$ & $5.81 \pm 0.29^{\mathrm{a}}$ & $5.72 \pm 0.91^{\mathrm{a}}$ & $5.60 \pm 0.80^{\mathrm{a}}$ & $5.52 \pm 0.87^{\mathrm{a}}$ \\
$\mathrm{pH}$ & $8.02 \pm 0.30^{\mathrm{a}}$ & $8.09 \pm 0.33^{\mathrm{a}}$ & $8.11 \pm 0.34^{\mathrm{a}}$ & $8.01 \pm 0.35^{\mathrm{a}}$ \\
EC $(\mu \mathrm{S} / \mathrm{cm})$ & $2468.22 \pm 912.80^{\mathrm{a}}$ & $2410.90 \pm 679.63^{\mathrm{a}}$ & $2640.86 \pm 965.67^{\mathrm{a}}$ & $2402.11 \pm 1043.90^{\mathrm{a}}$ \\
TDS $(\mathrm{mg} / \mathrm{L})$ & $1215.42 \pm 488.30^{\mathrm{a}}$ & $1194.58 \pm 292.47^{\mathrm{a}}$ & $1390.66 \pm 639.81^{\mathrm{a}}$ & $1188.05 \pm 509.47^{\mathrm{a}}$ \\
Salinity $(\mathrm{mg} / \mathrm{L})$ & $0.90 \pm 0.02^{\mathrm{a}}$ & $0.89 \pm 0.02^{\mathrm{a}}$ & $0.90 \pm 0.02^{\mathrm{a}}$ & $0.89 \pm 0.02^{\mathrm{a}}$ \\
\hline
\end{tabular}

For abbreviations, see Table II. 
$10 \%$ of $M$. oleifera meal and was significantly different to the control group $\left(\mathrm{T}_{0}\right)$ while highest one was recorded in fish feed carrying $30 \%$ of $M$. oleifera meal.

Proximate analysis of the fish fed on the four diets formulated for the experimental trial is presented in Table III. A significantly higher proportion of crude protein $(62.45 \pm 0.15 \%)$ was observed in $\mathrm{T}_{3}$ that was notably different from the control group $\left(\mathrm{T}_{0}\right)$. The maximum fat content $(8.67 \pm 0.03 \%)$ was found in $\mathrm{T}_{2}$ exhibiting significantly greater content than $\mathrm{T}_{1}(6.53 \pm 0.04 \%)$ and control $\mathrm{T}_{0}(5.70 \pm 0.05 \%)$ fish. Ash content in $\mathrm{T}_{0}$ $(6.80 \pm 0.08 \%)$ was significantly higher than all other diets. No difference in moisture content was found in fish fed the different diets. The dry matter of the fish sampled in $\mathrm{T}_{2}$ and $\mathrm{T}_{3}$ showed significantly higher values $(\mathrm{P}<0.05)$ than $\mathrm{T}_{1}$.

Physico-chemical parameters of the water exhibited non-significant results in all treatments (Table IV). A favorable temperature $\left(21-22^{\circ} \mathrm{C}\right)$ was recorded in all the treatment groups. The DO remained in the favorable range throughout the experiment $(5.72 \pm 0.91 \mathrm{mg} / \mathrm{L}$, $5.60 \pm 0.80 \mathrm{mg} / \mathrm{L}, \quad 5.52 \pm 0.87 \mathrm{mg} / \mathrm{L}$ and $5.81 \pm 0.29 \mathrm{mg} / \mathrm{L}$ for $\mathrm{T}_{1}, \mathrm{~T}_{2}, \mathrm{~T}_{3}$ and $\mathrm{T}_{0}$ groups respectively). During the whole experimental period the $\mathrm{pH}$ was stable at 8 in all the treatments. The maximum electrical conductivity $(2640.86 \pm 965.67 \mu \mathrm{S} / \mathrm{cm})$ was observed in $T_{2}$. No significant differences were found in salinity, TDS and nitrates among all the treatments (Table IV).

\section{DISCUSSION}

Fish demand is continuously rising globally due to its nutritious and healthy characteristics. The aquaculture industry is rising globally as the fastest growing fish producing sector (Ottinger et al., 2016). However, this industry is facing a lot of challenges to provide nutritionally balanced feed to fish. Increasing demands, high prices and limited supply of fish meal turn the attention of fish culturists to replace costly fish feed ingredients with alternatives which are cheaper and that are easily, locally and widely available. The chief protein source ingredient in fish feed is fishmeal. Plant derived protein is therefore a good potential substitute and the leaves of $M$. oleifera are a rich source of plant based protein (30\%) (Arsalan et al., 2016). Hence we have investigated the use of moringa leaf meal, at different inclusion levels, in fish diets.

In the present study the maximum weight gain was observed in $\mathrm{T}_{3}$, followed by $\mathrm{T}_{1}, \mathrm{~T}_{2}$ and $\mathrm{T}_{0}$. Highest length increase was seen in $\mathrm{T}_{2}$, followed by $\mathrm{T}_{1}, \mathrm{~T}_{3}$ and control groups. Yuangsoi and Matsumoto (2012) showed that when soybean meal was replaced with $M$. oleifera leaf meal (MOLM) it affected the growth performance and fish (fancy carp) digestibility. Hence, MOLM could be replaced not up to $20 \%$ of plant protein in soybean. Continuous rise in the replacement of fish meal (animal protein) with $M$. oleifera leaf meal (MOLM) could slow down the growth of aquaculture (Richter et al., 2003). Ritcher et al. (2003) observation was further supported by El-Nadi (2015) when it was shown that growth performance of $O$. niloticus decreased with the increase of $M$. oleifera plant meals in the diet. Further, substitution of $55 \%$ MOL meal for soybean meal awarded the best growth performance (less than $7.34 \%$ ) and feed nutrient utilization in $O$. niloticus was explored by Tiamiyu et al. (2016). While the present study shows contradictory results to those of Ozovehe et al. (2013). These authors reported that growth and feed consumption of fish, Clarias gariepinus decreased with increasing proportion of MOLM in fish feed. Afuang et al. (2003) described that solvent extracted MOLM could replace $30 \%$ fishmeal in the feed of $O$. niloticus. Mehdi et al. (2016) studied the effect of M. oleifera on the growth of Labeo rohita and found that $10 \%$ inclusion of this plant is better for the growth of this species, beyond this it has negative effect which may be due to presence of antinutritional factors or amino acid imbalance. However, the results of the present study showed that increase in $M$. oleifera meal replacing soybean meal increases the $L$. rohita growth.

The products derived from $M$. oleifera have been explored as important ingredients for practical feed of $L$. rohita. The findings of the present study revealed that MOLM could be used as a protein substitute up to inclusion levels of $20-30 \%$ in diets for growing L. rohita. The findings of our study are broadly in agreement with that of Ncha et al. (2015) who demonstrated that fish fed $0 \%$ MOLM diet exhibited a peak value of 6.59 and lowest value of 5.86 in fish given a 60\% MOLM diet. Karina et al. (2015) replaced soybean meal with MOLM to give levels of $0 \%, 8 \%, 16 \%, 24 \%$ and $32 \%$, and found highest SGR in fish fed a diet with $32 \%$ MOLM $(1.45 \pm 0.09 \%)$. However,

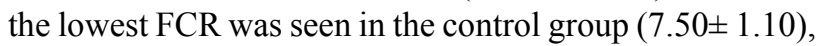
while the highest value was found in fish given the $32 \%$ inclusion (9.96 \pm 0.13$)$. Similarly, increment in the FCR values were also recorded in Nile tilapia with the inclusion increment of moringa leaves in diet which is an indication of presence some anti-nutrients (Richter et al., 2003).

The crude fat content was found to increase with increasing moringa meal up to $20 \%$. This data agrees with results from Mehdi et al. (2016) where increase in fat was observed in fish being fed up to $20 \%$ moringa meal in $L$. rohita. Further, the present research supports the results of Ganzon-Naret (2014) where an increased proportion of crude fat was found on addition of MOLM in Asian sea bass (Lates calcarifer) diets. Our results differ from other 
experiments, reported the highest value of crude fat in different fish species using 10\% MOLM in diets (Olaniyi et al., 2013; Thiam et al., 2015; Arsalan et al., 2016).

In the present study, all physico-chemical parameters of water exhibited no significant differences between the treatment groups.

\section{CONCLUSION}

In conclusion, the current research shows that $M$. oleifera meal could be used safely for promoting the growth of fish without any harmful effects on body composition of $L$. rohita. Our results show that $M$. oleifera meal inclusion up to $20-30 \%$ is suitable to replace soybean meal in fish diets.

\section{Conflict of interest}

The authors declare that they have no conflict of interest.

\section{Ethical approval}

All applicable international, national, and/or institutional guidelines for the care and use of animals were followed by the authors.

\section{REFERENCES}

AOAC. 2006. Association of official analytical chemists, $17^{\text {th }}$ Edition. Method number 1125.

Afuang, W., Siddhuraju, P. and Becker K., 2003. Comparative nutritional evaluation of raw, methanol extracted residues and methanol extracts of moringa (Moringa oleifera L.) leaves on growth performance and feed utilization in Nile tilapia (Oreochromis niloticus L.). Aquacul. Res., 34: 1147-1159

Arsalan, M.Z.H., Hussain, S.M., Asrar, M., Anwar, H., Rehan, M.M.H., Shahzad, M.M., Riaz, D., Ahmad, N. and Wahab, N., 2016. Effects of Moringa oleifera leaf meal (MOLM) based diets on carcass composition and hematology of Labeo rohita fingerlings. J. Biodivers. environ. Sci., 9: 214-223.

Barros, M.M., Lim, C. and Klesius, P.H., 2002. Effect of soybean meal replacement by cottonseed meal and iron supplementation on growth, immune response and resistance of channel catfish (Ictalurus puctatus) to Edwarsiella ictalurid challenge. Aquaculture, 207: 263-279. https://doi.org/10.1016/S00448486(01)00740-2

Citarasu, T., 2010. Herbal biomedicines: a new opportunity for aquaculture industry. Aquacul. Int., 18: 403-414. https://doi.org/10.1007/s10499-009-
9253-7

El-Nadi, A.S.M. and Khames, M.K., 2015. Effect of Dietary supplementation with (Moring aoleifara) leaves on growth performance parameters on Nile tilapia (Oreochromis niloticus). Res. J. Fish. Hydrobiol., 10:10-14.

Ezekiel, O.A., Fidelis, B.A. and Grace, N.U., 2016. Effect of partial replacement of fishmeal with Moringa oleifera Leaf meal on the haematology, carcass composition and growth performance of Clarias gariepinus (Burchell 1822) fingerlings. Int. J. Fish. aquat. Stud., 4: 307-311.

Gabriel, U.U., Akinrotimi, O.A., Bekibele, D.O., Onunkwo, D.N. and Anyanwu, P.E., 2007. Locally produced fish feed, potentials for aquaculture development in sub-saharan. Afr. J. agric. Res., 297: 287-295.

Ganzon-Naret, E.S., 2014. Utilization of Moringa oleifera leaf meals as plant protein sources at different inclusion levels in fish meal based diets fed to Lates calcarifer. ABAH Bioflux., 6: 158-166.

Hashem, H., El-Rahman, A., Hanan, A., Ali, A.S.M., Abozaid, E.H., Mamdouh, I., El-Fetoh, M.A. and Abdall, M., 2017. Growth performance, feed utilization and body composition of nile tilapia (Oreochromis niloticus) fingerlings fed moringa (Moringa oleifera Lam.) seed meal. J. Fish. aquat. Sci., 12: 36-41. https://doi.org/10.3923/ jfas.2017.36.41

Karina, S., Akbar, M., Supriatna, A. and Muchlisin, Z.A., 2015. Replacement of soybean meal with Moringa oleifera leaf meal in the formulated diets of tilapia (Oreochro misniloticus) fingerlings. Int. J. Bioflex Soc., 8: 790-795.

Luqman, S., Srivastava, S., Kumar, R., Maurya, A.K. and Chanda, D., 2012. Experimental of moringa oleifera leaf and fruit for its antistress, antioxidant and scavenging potential using in vitro and in vivo assay. Evidence-Based Complem. Altern. Med., 1-12. https://doi.org/10.1155/2012/519084

Makkar, H.P.S. and Becker, K., 1996. Nutritional value and antinutritional components of whole and ethanol extracted Moringa oleifera leaves. Anim. Feed Sci. Tech., 63: 211-228. https://doi. org/10.1016/S0377-8401(96)01023-1

Mehdi. H., Khan, N., Iqbal, K.J., Rasool, F., Chaudhry, M.H. and Khan, K.M., 2016. Effect of Moringa oleifera meal on the growth, body composition and nutrient digestibility of Labeo rohita. Int. J. Biosci., 8: 11-17. https://doi.org/10.12692/ijb/8.4.11-17

Ncha, O.S., Michael, P.B., Nnabuchi, U.O. and Alex, E., 2015. Effect of diets with moringa leaf meal on 
growth, carcass composition and haematology of Clarias gariepinus. Int. Fish. aquat. Stud., 3: 397401.

Olaniyi, C.O., Ajani, N.O. and Adetomi, M.N., 2013. Growth performance and nutrient utilization of Clarias gariepinus fed moringa oleifera leaf meal. Int. J. Nat. Sci. Res., 3: 99-104.

Ottinger, M., Clauss, K. and Kuenzer, C., 2016. Aquaculture: Relevance, distribution, impacts and spatial assessments - A review. Ocean Coastal Manage., 119: 244-266. https://doi.org/10.1016/j. ocecoaman.2015.10.015

Ozovehe, B.N. and Nzeh, G.C., 2013. Effects of varying levels of Moringa oleifera leaf meal diet on growth performance, hematological indices and biochemical enzymes of African catfish Clarias gariepinus (Burchell 1822). Elixir Aquacul., 57: 14459-14466. https://doi.org/10.4172/21559546.1000166

Petricorena, Z.C., 2014. Chemical Composition of Fish and Fishery Products. In: Handbook of food chemistry (ed. P. Cheung). Springer, Berlin, Heidelberg. https://doi.org/10.1007/978-3-64241609-5_12-1

Richter, N., Siddhuraju, P. and Becker, K., 2003. Evaluation of nutritional quality of Moringa (Moringa oleifera Lam.) leaves as alternative protein source for tilapia (Oreochromis niloticus L.). Aquaculture, 217: 599-611. https://doi. org/10.1016/S0044-8486(02)00497-0

Shalaby, S.M.M., 2004. Response of Nile tilapia,
Oreochromis niloticus, fingerlings to diets supplemented with different levels of fenugreek seeds (Hulba). J. Agricult. Mansoura Univ., 29: 2231-2242.

Soliva, C.R., Kreuzer, M., Foid, N., Foid, G., Machmuller, A. and Hess, H.D., 2005. Feeding value of whole and extracted Moringa oleifera leaves for ruminants and their effects on ruminal fermentation in vitro. Anim. Feed Sci. Technol., 118: 47-62. https://doi. org/10.1016/j.anifeedsci.2004.10.005

Storebakken T., Refstie S. and Ruyter, B., 2000. Soy products as fat and protein sources in fish feeds for intensive aquaculture (ed. J.K. Drackly). Soy in Animal Nutrition, Federation of Animal Science Societies, Savoy, IL. pp. 127-170.

Thiam, S., Fall, J., Loum, A., Sagne, M. and Diouf, M., 2015. Use of effective microorganisms (em) in tilapia diets: Effects of growth performance and carcass composition. Int. J. Curr. Microbiol. appli. Sci., 4: 536-49.

Tiamiyu, L.O., Okomoda, V.T. and Aende, A., 2016. Growth performance of Oreochromis niloticus fingerlings fed Moringa oleifera leaf as replacement for soybean meal. J. Aquacult. Eng. Fish. Res., 2: 61-66. https://doi.org/10.3153/JAEFR16008

Yuangsoi, B. and Masumoto, T., 2012. Replacing moringa leaf (Moringa oleifera) Partially by protein replacement in soybean meal of fancy carp (Cyprinus carpio). Songklanakarin J. Sci. Technol., 34: 479-485. 